\title{
DESIGN OF A VARIABLE-FLOW-RATE, SINGLE-PASS LEACHING SÝSTEM
}
H. C. Weed
D. D. Jackson

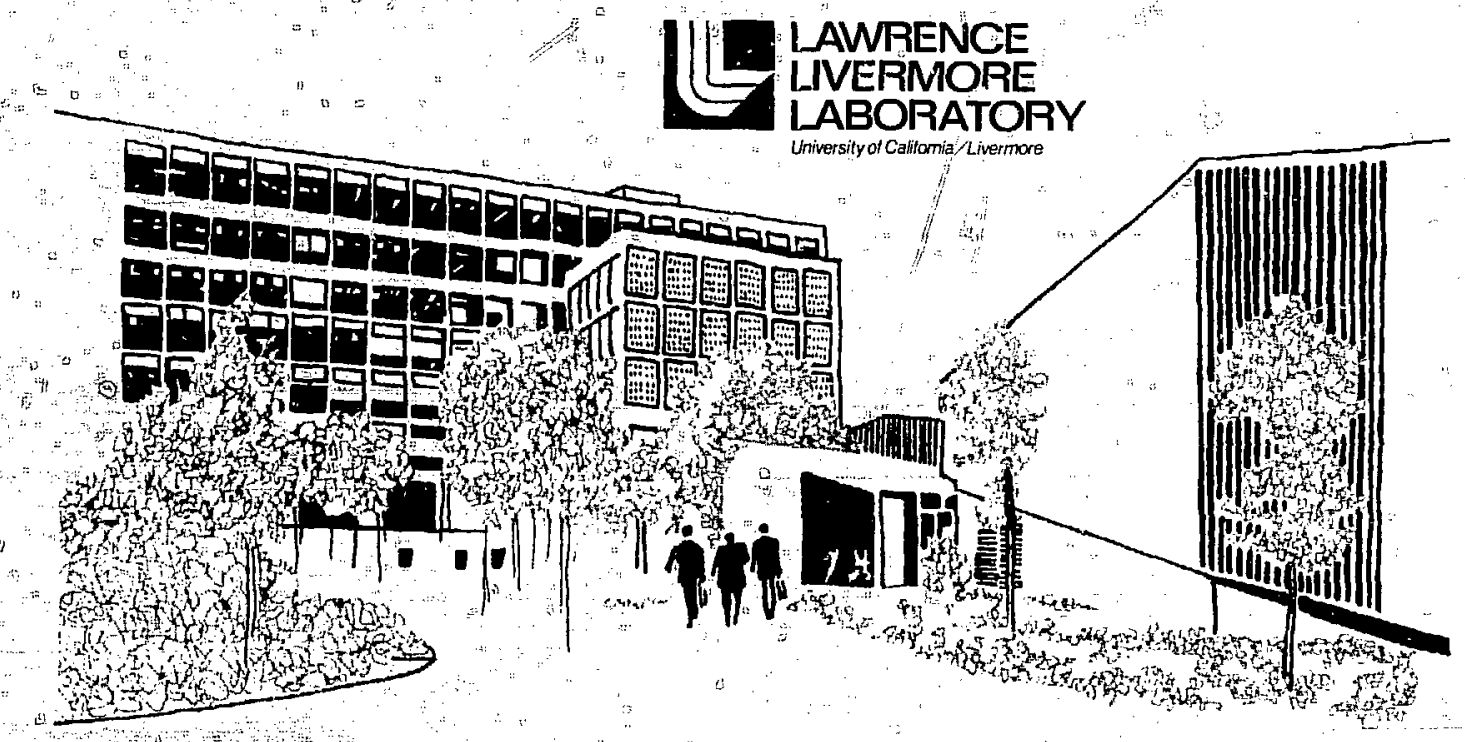




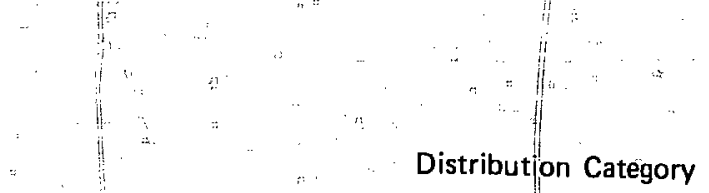

UC-37

\section{LAWRENCE LIVERMORE LABORATORY University of Cahtornia Livermore, Calitomia 94550}

\section{DESIGN OF A VARIABLE FLOW-RATE, SINGLE-PASS LEACHING SYSTEM}

$\mathrm{H}:$ C. Weed $:$

D. D. Jackson

MS. date: $\operatorname{May}_{:} 30,1979$ 5

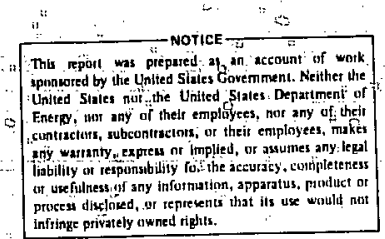

infringe privivately awned rights. 


\section{FOREWORD}

Encouragement and support wereprovided initially by $R$. Ide. We thank D. Coles for devising the pelletizing technique used to prepare the effluent samples for counting, and for much valuable information on the application of radiochemicaidmethods to the leaching problem. D: Hansen advised on the design of the sample holder and supervised the fabrication of the prototype. R. Flores ind P. Bowen fabricated and assembled the system, and J. Bushman and " M. Edwards modified and maintained it.: J. Schweiger performed the initial flow-rate calibration runs and monitored the performance of the system during routine operation. The funding for the development of the apparatus described "in. this document was provided by the Nevada Test site environmental program "Radionuclide Migration in the Ground."

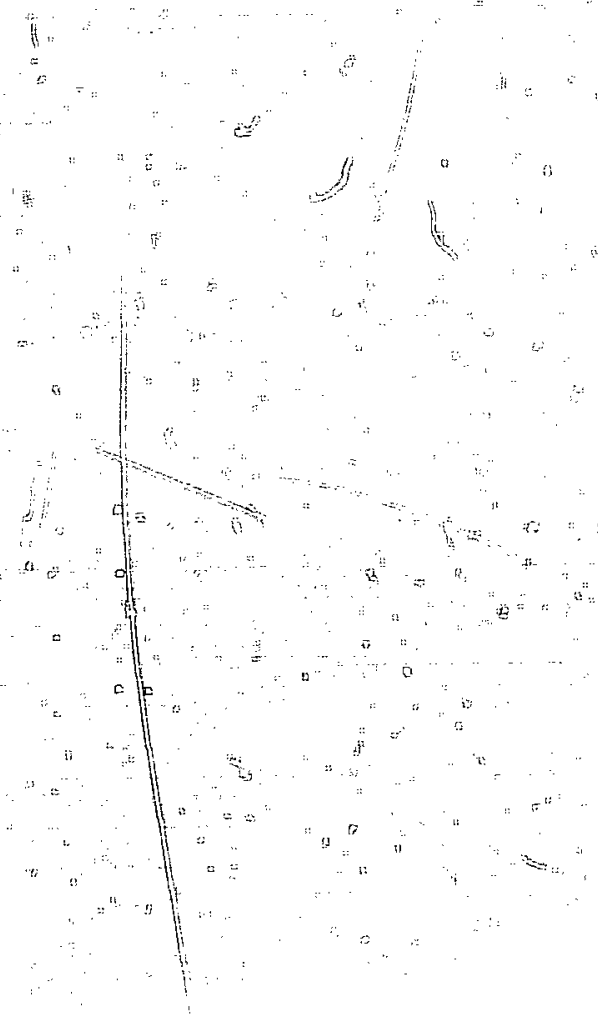


CONTENTS

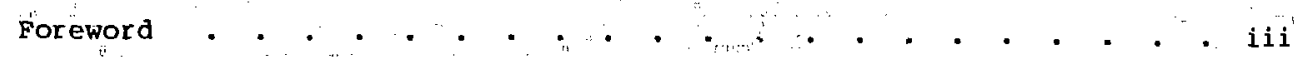

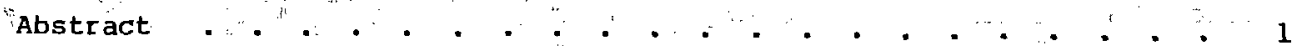

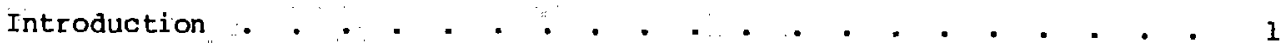

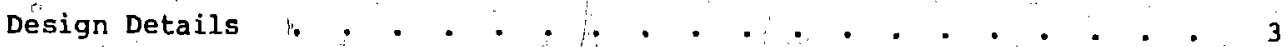

Overall System . . . . . . . . . . . . . . . . . . . . 3

Metering Pumps . • . . . . . . . . . . . . . . . . 3

Sample Holder . • • •

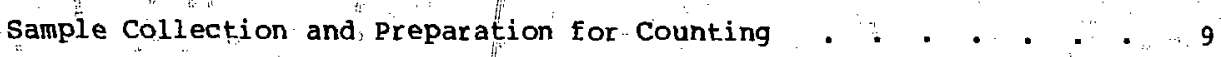

Cost .. . . . . . . . . . . . . . . . 11

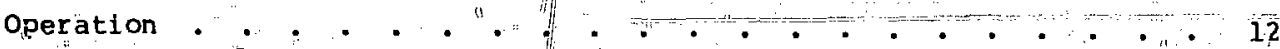

start-up . . . . . . . . . . . . . . . 12

Routine Operation . . . . . . . . . . . . . . . . . 12

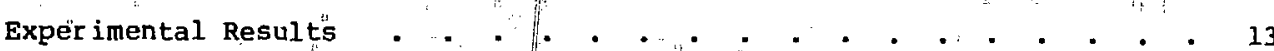

Conclusions . . . . . . . . . . . . . . . . . . . 16

References 


\section{LIST OF ILLUSTRATIÓNS}

2.: One-pass leaching system--general view

3. One-pass leaching system-detalls of pumps, sample holders, andirecelvers

4. Air inlet to reservoir.

5. Sample-holder assembly, one-pass leakhing system

6. Sample-holder assembly

$=7$ - Leach $=$ rate of co isotope
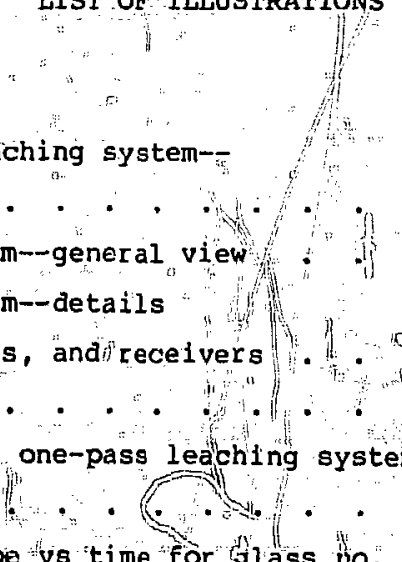

1. One-pass continuous leaching system--

"functional diagram

(
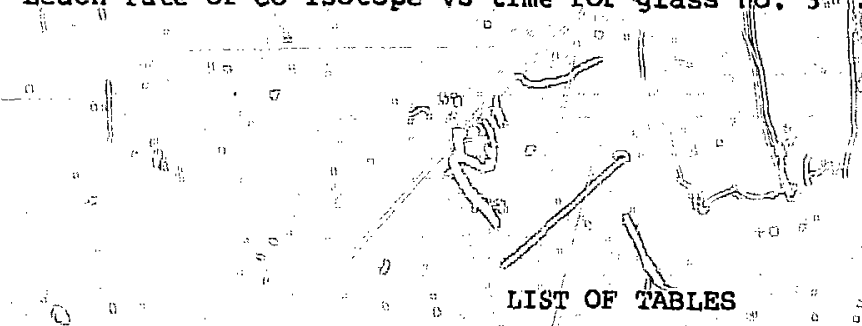

1. Characteristics of the one-pass leaching-system

\% for the radionuclide migration/program at LLL

2. Approximate equipment costs, one-pass leaching system for the radionuclide migration program at LLL

3. Leaching rates for co isotopes in glass no. 3

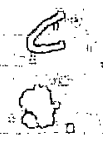


DESIGN OF A VARIABLE-FLOW-RATE,

SINGLE-PASS LEACHING SYSTEM

We have designed leaching systems for experiments on severallinds of solitds, ingluding glassy debris from underground nuclear explosions at Nevada Test Site (pudale glass), refractory compositions for retention of radioactive nuclear reactor waste, and spent reactor fuel. "The system used on pudale glass has a continucusly variable flow rate $f r o m ~ 13$ to $460 \mathrm{~cm}^{3} / \mathrm{d}$, a temperature rarge from 25 to $75^{\circ} \mathrm{C}$, operating capacity for up to 2 similtaneous experiments, and one-pass operation with continuous exposure of samples to fresh solution. Results obtained on pudale glass ale in qualitative agreement with those on silicate glasses designed for isol ation of nuclear reactor waste.

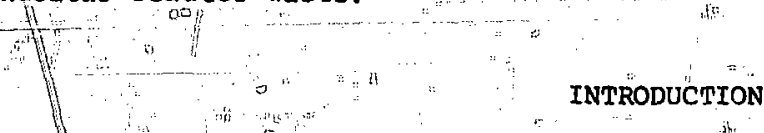

INTRODUCTION

Programs at Lawrence Livermore Laboratory of ten require exp/erimentai studies of the interactions of solid materials with groundwatef/f Fr example the enviconmental program at the Nevada Test site (NTS) is concerned with the leaching of glassy debris (pudale glass) from underground nuflear explosions. The Waste Isolation Safety Assessment Program of the Nationaly waste Terminal storage program is also concerned with the durability of refractory compositions for the retention of Eadioactive nuclear wastes. This report Wild deschibe a "one-pass" leaching system, originally deyeloped for the NTS program, which has been used to determine dissolution cates for puctale chass in water.

Many different systems have been used for leaching tests, as shown fin the reviey by Mende 1 . The systems can be either static/or aynamic. For purposes of thisfascussion, static systems are those without mechanical agitation of the liquid. The simplest static syster is a sealed vessel at róntemperature with the sample Immersed in stagnant 1 ilguid. $2,3,4$ If the vessel is heated, the system becomes quasi-static because of convective mixing 5,6 to the solid sample, either by mechanical agitation of a fixed volume of 
liquid around it, or by flowing liquid past it in a sample chamber Dynamic systems can be further classified as intermittant ${ }^{6} 7$ vs continuous, $5,8,9$ or single-pass $5,7,9-12$ vs multiple-pass 8,13 Multiple-pass systems are probably used more than single pass systems in measuring low-leach rates. This is done "principally to reduce the amount of water, which simplifies the experimental system. Multiple-pass systems such as soxhlet extractors, 7 reflux extractors, ${ }^{5}$ of recirculating ion-exchange $=c^{\circ}{ }^{8}$ expose the solid samples to distilled or deionjzed water, therefore, they are not used to investigate the effects of ionic solutions. Single-pass"flow systems are less comiton than multiple-pass systems, but have the potential advantage of more glosely simulating the leaching agtion of natural waters.

static systems and some of the multiple-pass dynamic systems operate with coñstant volumes of liquid, which are completely changed at predetermined intervas, In such systems leak ching may be retarded by the increasing concentration of leaphed ions ifh solution. "Dynamic systems in which the sample is always exposed to fresh leach solution control the concentration increase csome kinetic effects can be studied in them by adjusting the flow rate and ghence the extent of esorption and other back reactions. The single-pass system to be described was originally designed to simulate Treported flow rates for Nos and to have the following desirable characteristics:

$=-$ maximum retention of solid particles,

- minimum soyption of activity by the filter of sample holder

iow costand ready availability of the filter, lowsistance to solution flow, compact size of the activity-containing part of the assemin.

7 The present design dilows the foryowing experimental parameters to be explored: composition and particle size of the solid t of aspect/ratio of, he sample assembly and sample in
soilution composilion, such as distilied water, solution composilion, such as distilied water, appropriate groundwater, or synthetic electrolyte, temperature. flow rate, frequency of sampling 


\section{DÉSIGN DETAILS}

OVERALL SYSTEM

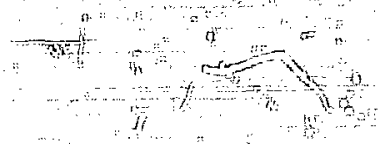

A functional diagram is shown in Fig. 1 , and the assembled 20-channel system in Figs. 2 and 3. The main supply tank, constant-level tank, supply manifold, and final filters conpeitute a Gravity-fed supply syster for the peristaltic-type metering pumps The final filters have a pore size equal to that of the filters in the sample holders in order to prevent clogging]os the sample, holders by organic or inorganic particulates in ine leaching solution. Valves áre included between supply manifold and final fil ters to allow them to be replaced if necessary. The effluent from the sample holders flows through $0.69 \mathrm{~mm}(0.027$ in. I.D. tubing into plastic bottles through small holes $\mathrm{n}$ the lids.

Since it was anticipated that the experiments might last as long as 30 months, the leach solution stored in the supply tanks is protected from evaporation by air inlets. These are small containers (A and B) of leach solution, as shown in Fíg, 4 Containers $A$ and $B$ are connected near the bottom so that as air flows in either directiono it bubbles through the solution in the tube. This saturates the air with respect to the water in the solution. Assuming that $\mathrm{P}_{1}<\mathrm{P}_{2} \leq \mathrm{P}_{3}$ because Raoult's Law holds to a better and better approximation for the water in the vapor phase in containers $A$ and $B, P_{3}$ (the resulting partial pressure of water in contajner $B$ ) is approximately/the same as in the supply tank, so that water does not evaporate from the supply tank. Thus, onlyair is transported between the tank and" laboratory atmosphere with changes in barometric pressure or water level ing

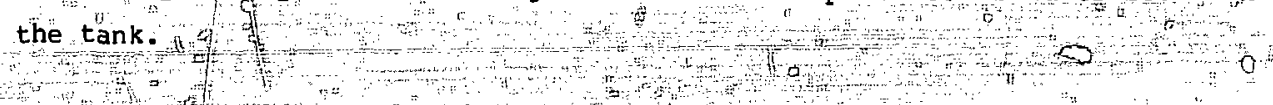
METERING QUMPS

Each pump assembly consists of a chassis and from 1 to To cassettes. The chasuis contains the electric motor with a continuously var lable speed control, and the drive train, which terminates, in two cassette gears. "The 1ow-speed gear drives the cassettes wh they are clamped in the chassis in 3 


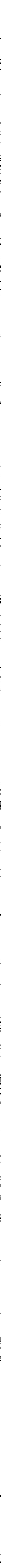




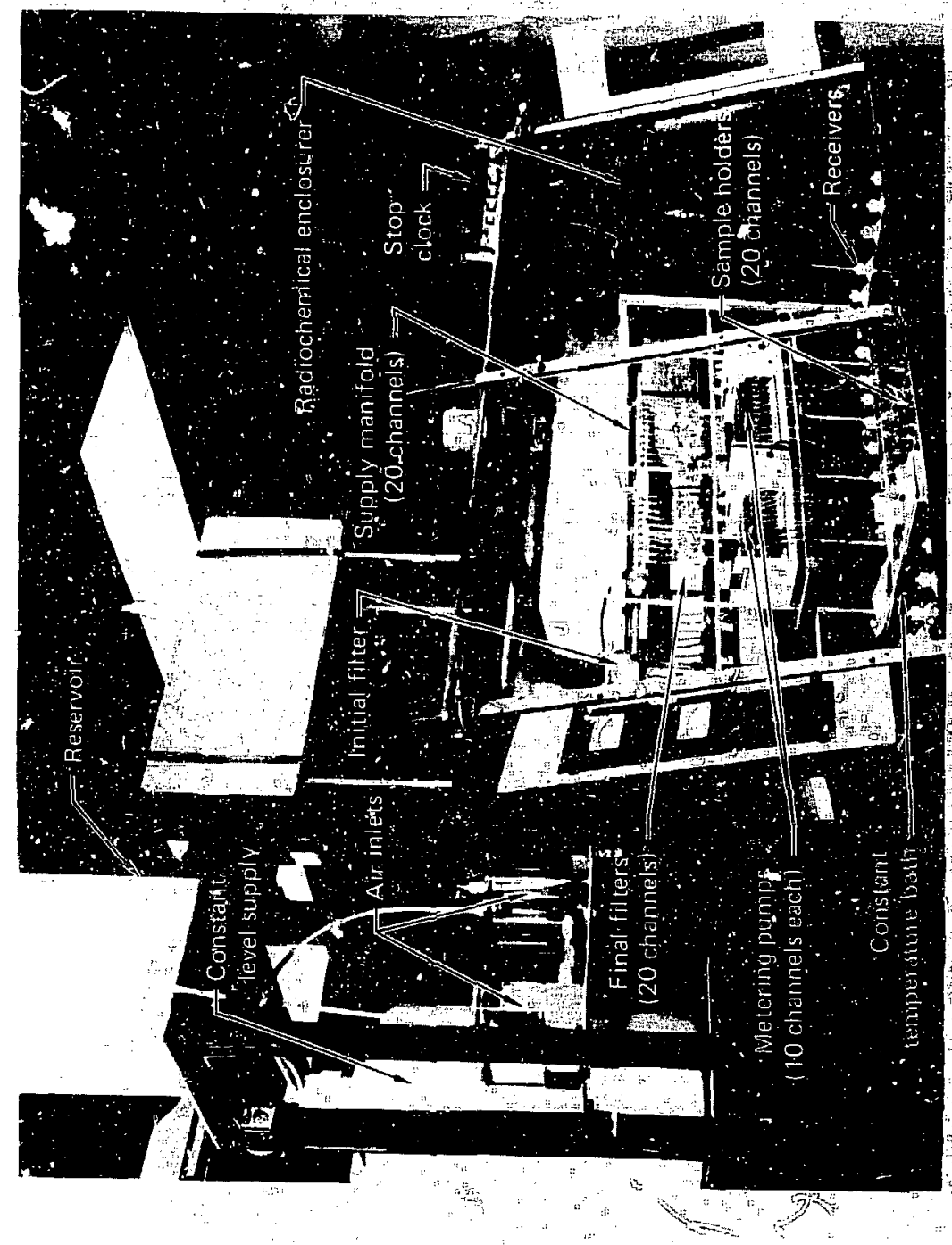




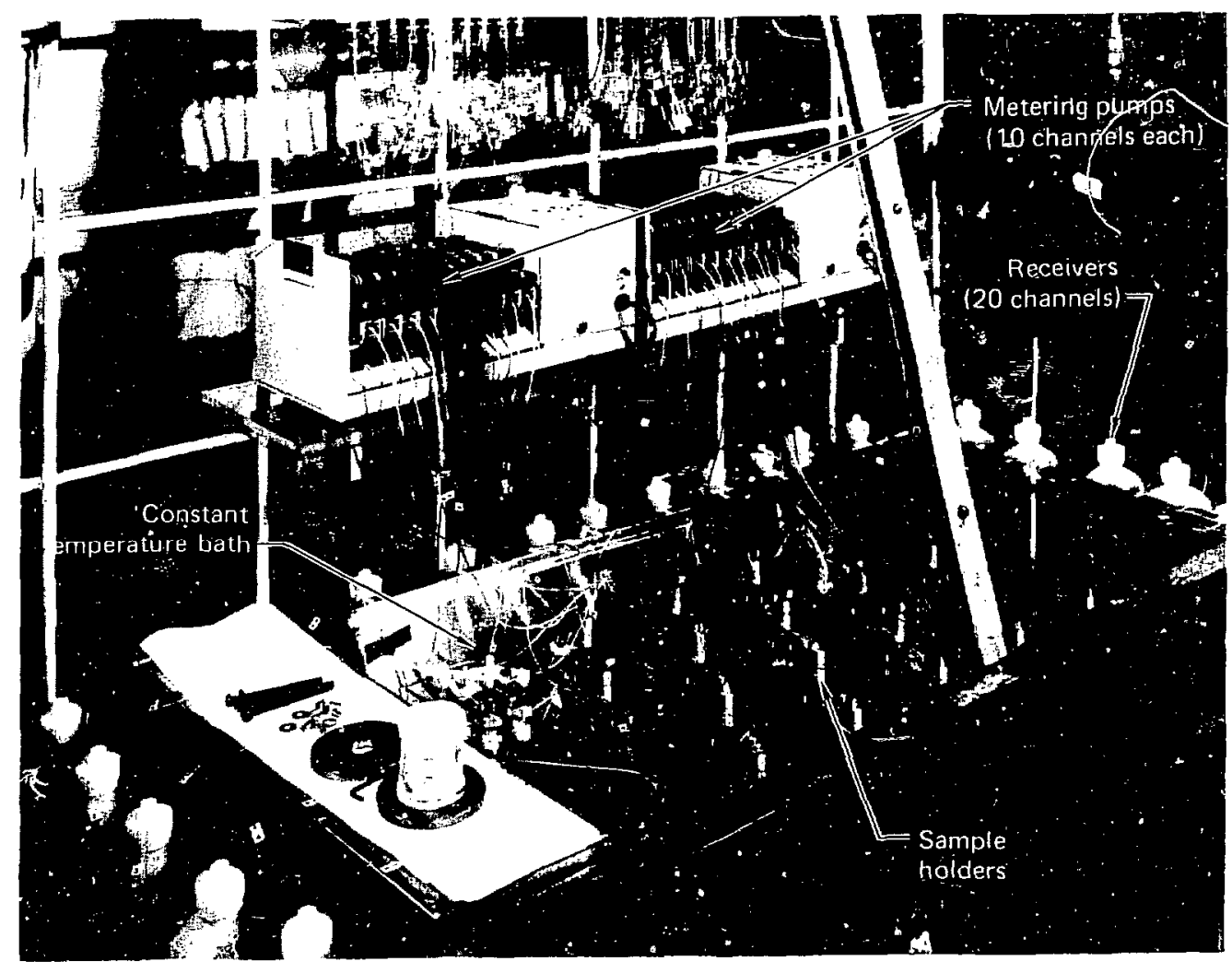

FIG. 3. One-pass ieaching system-details of pumps, sample holders, and receivers. 


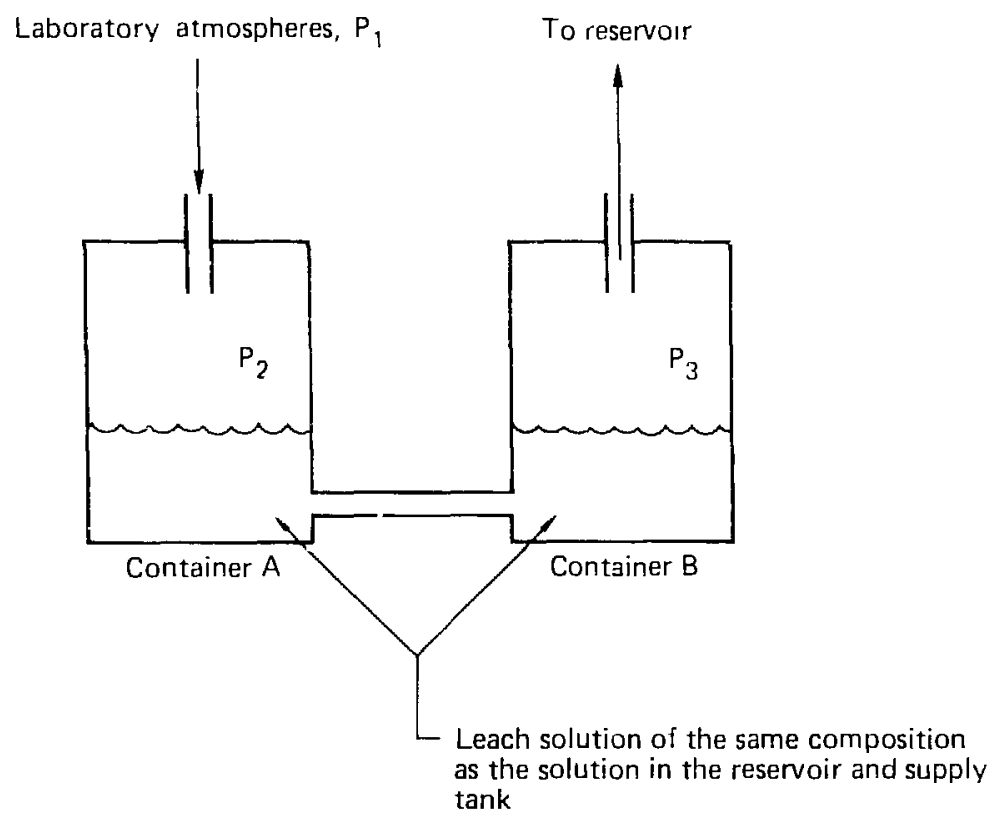

FIG. 4. Air inlet to reservoir.

one orientation, and the high-speed gear drives them when they are in the other orientation. Each cassette controls a single channel; the peristaltic action of the cassette is produced by rollers squeezing a silicone polymer tube against a curved backing plate. Punping rate is determined by the cassette orientation in the chassis, the continuously variable speed setting for the electric motor, and the inside diameter of the tube. Flow rates vary from 13 to $460 \mathrm{~cm}^{3} / \mathrm{d}$ as shown in Table 1 . The corresponding linear flow speeds are 9 to $331 \mathrm{~m} / \mathrm{yr}$ for a 25- $\mathrm{mm}$ diameter sample cell. These rates were chosen early in the design of the system to correspond as nearly as possible to groundwater flow rates for the Nevada Test site of 1.8 to $180 \mathrm{~m} / \mathrm{yr}$ at Yucca Flat. and 2 to $76 \mathrm{~m} / \mathrm{yr}$ at pahute Mesa. 14 
TABLE 1. Characteristics of the one-pass leaching system for the radionuclide migration program at LLL.

Flow rates:

Operating temperature:

Volume of powder sample:

Number of types of solutions, for each pump:
High range

$26-460$

18-331

$25.4 \mathrm{~mm}$

$0.1 \mu \mathrm{m}$

Pore size:

$25-75^{\circ} \mathrm{C}$

$2.1 \mathrm{~cm}^{3}$ maximum
Low range

13-158

9-114

up to 10

SAMPLE HOLDER

A cross-sectional view of an assembled holder is shown in Fig. 5, and its components in Fig. 6. The sample-holder material is polymethyl methacrylate (PMMA). Other materials such as Teflon could be used, but PMMA has the advantage of transparency, so that one can ubserve the sample during experiments. The end plugs and associated grids and 0-ring seals hold the filters in place at the ends of the sample chamber. The filters are 25-mm diameter Nuclepore polycarbonate membranes with pore size selected to be about 108 of the minimum sample-particle-diameter in order to ensure complete retention of the solid particles and to minimize clogging of the pores. The side opening is used to introduce powdered samples, or to remove air bubbles, which sometimes collect in the sample chamber during operation. The assembly is axially aligned by the sleeve and bolted together through the end plates. The sleeve has enough clearance at each end so that end load is supported by the end plugs and sample chamber. The load is adjusted by tightening the tension bolts to a torque reading of $0.64 \mathrm{~N} \cdot \mathrm{m}$ ( $5 \mathrm{in} \cdot 1 \mathrm{~b})$. The length of the sample chamber can be increased up to about 1 m and is probably limited only by the length for which the axial-alignment sleeve can be made with sufficient accuracy. Luer fittings are used to connect the sample chamber to the 
small-bore Teflon entry and exit tubes in order to simplify the design of the end plugs. Although the system is made of plastic, we do not anticipate any problem from radiation damage due to "hot" samples or effluent solutions.

SAMPLE COLLECTION AND PREPARATION FOR COUNTING

In order to sample the effluent, the appropriate collection bottle is removed and weighed, and the effluent is transferred to a plastic bag held in another bottle. The water is evaporated leaving the water-soluble residue in the bottom of the bag. The bag and residue are then folded up, inserted into a $31.75 \mathrm{~mm}$ (1.25 in.) die, and compacted into a right-circular cylinder by heating in a press to $100^{\circ} \mathrm{C}$ under a ram pressure of $30.3 \mathrm{MPa}$ (4400 psi). The heating time required is $10 \mathrm{~min}$. The resulting cylinder containing the leached activity is gamma-counted to determine the aciivity level.

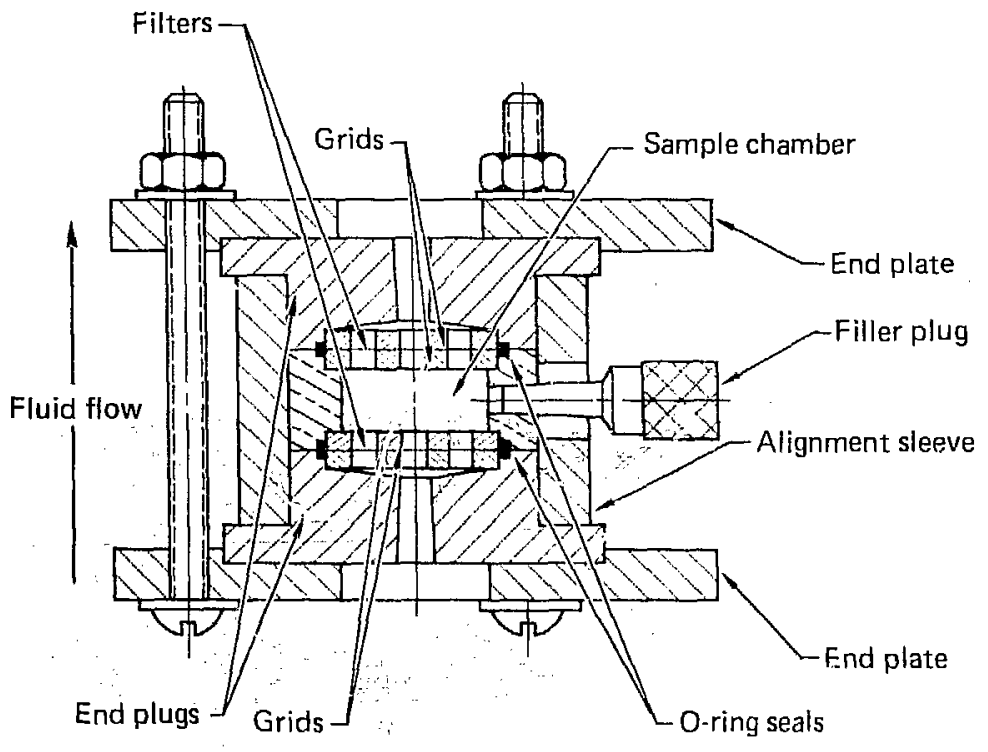

FIG. 5. Sample-holder assembly, one-pass leaching system. 


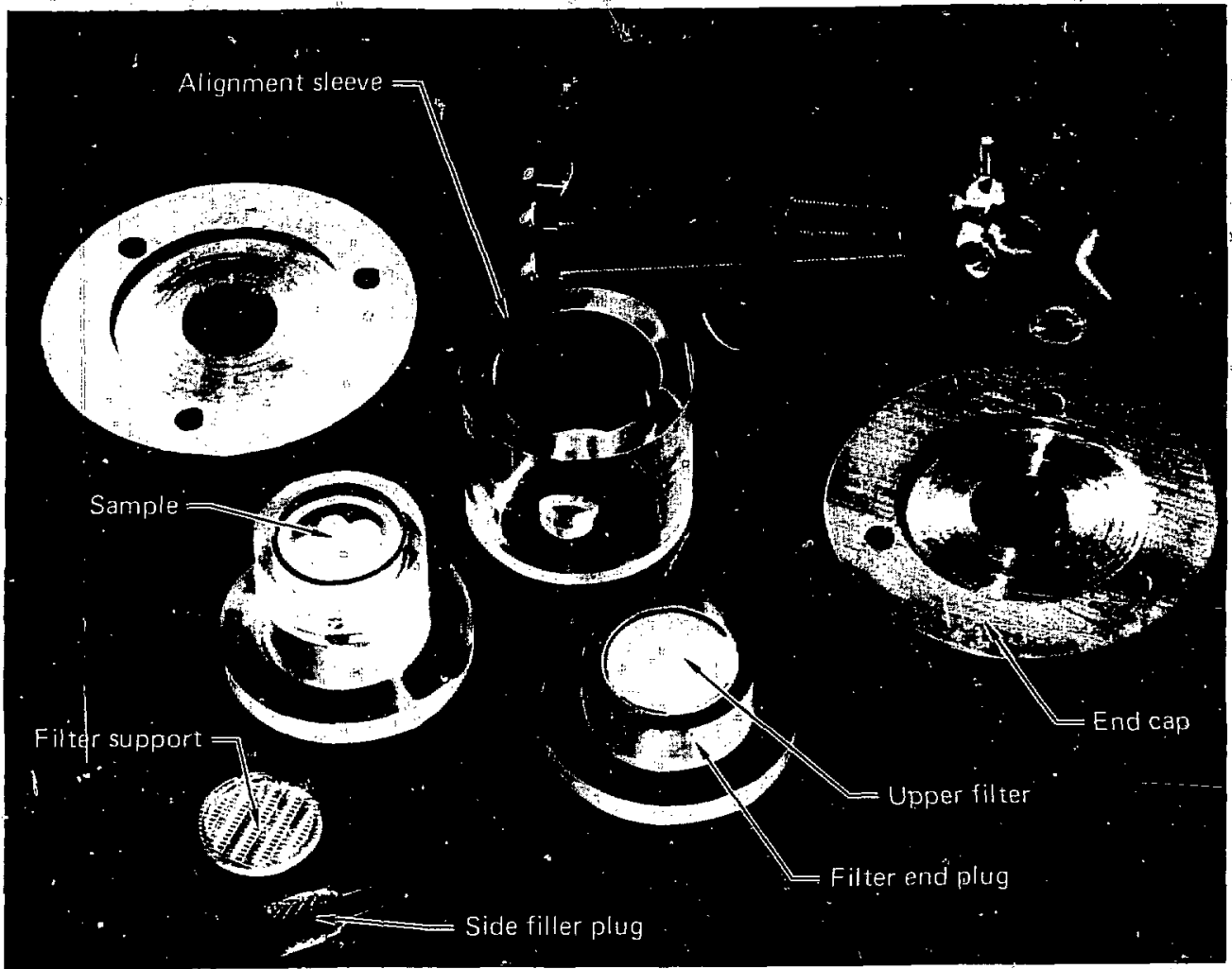

FIG. 6. Sample-holder assembly. 
An alternative sampling procedure has been considered, in which the effluent from the sample containers is not weighed, but instead is passed through ion-exchange résin columns. These would then be eluted at suitable intervals, and the eluate counted. If ion-exchange columns were being used as collertors, the effluent from them would be low-conductivity water. The conductivity of the effluent could be monitored so that if break-through and consequent increase in conductivity occurred, the effluent in the waste receiver could be reprocessed.

CosT

The current costs of the components of the system for the 20-channel installation shown in Figs. 1 to 5 are shown in Table 2. They do not include costs for the radiochemical enclosure or for fabrication and assembly of the system.

TABLE 2. Approximate equipment costs, one-pass leaching system for the radionuclide migration program at LLL.

\begin{tabular}{|c|c|c|}
\hline 2 & Pump drive chassis e $\$ 500$ & $\$ 1,000$ \\
\hline 20 & Pump cassettes e $\$ 60$ & 1,200 \\
\hline 20 & Sample holders e $\$ 90$ & 1,800 \\
\hline 2 & Reservoirs $\$ 40$ & 80 \\
\hline 1 & Constant temperature water bath $9 \$ 720$ & 720 \\
\hline 1 & Prefilter Unit e\$110 & 110 \\
\hline 21 & Plastic tubing assemblies $e \$ 25$ & 525 \\
\hline 1 & Manifold e\$100 & 100 \\
\hline $1=\ldots$ & Constant level assembly e $\$ 120$ & 120 \\
\hline & TOTAL & $\$ 5,655$ \\
\hline
\end{tabular}




\section{OPERATION}

START-UP

Before introduction of a sample, each sample holder is tested for leaks by pressurizing it with $\mathrm{N}_{2}$ to $136 \mathrm{kPa}(5 \mathrm{psig})$ and submerging it in a one-liter beaker of water. The sample holder is dried and a Eunnel is inserted in the filler entrance. Room air is drawn into the sample chamber through the funnel and out of it through one of the $0.1-\mu m$ filters and the supporting end plug by connection to a vacuum line. Weighed amounts of sample are poured into the chamber through the funnel; the air current prevents dust from spreading on the outside of the assembly. The funnel is removed, the filler plug inserted, and the vacuum line then removed. Enough water to fill the sample chamber almost completely is introduced a drop at a time through the filler entrance using a blunt 22-gauge reedle and 10-cc hypodermic syringe. The inlet end chamber is also filled with the syringe, and the inlet line from the metering pump is plugged into it. The filling time is noted. The effluent line is then connected to the sample holder and effluent receiver, and the sample assembly placed in the constant temperature bath. This starts the leaching experiment for the sample. In most of the sample chambers the flow direction is upward, but as partial check on the effect of flow direction, two sample chambers are installed with flow direction downward.

ROUTINE OPERATION

The main tasks during routine operation are collection, weighing, and evaporation of effluent samples. However, a considerable amount of maintenance is also necessary. This includes replacement of worn silicone pump tubing, replacement of final filters as they become clogged by particulates or bacterial growth, and removal of air from the sample chambers to keep the bubbles from blocking. fluid flow through the chambers.

On each of the sampling days, a cumulative sample is taken, which includes all the effluent collected since the previous sample. Aliquots of the cumulative sample are then taken for analysis. For instance, cumulative samples on days $1,2,3$, and 6 have intervals of $1,1,1$, and 3 days, respectively. For this reason, the results are averages over the sampling intervals. 
The experimental data consist of the initial sample weight, radionuclideactivity level, and surface area; and temperłture readings, effluent weights, and radionuclide-activity levels as functions of time. Mean times, flow rates and leach rates are calculated from these data as follows:

$$
\begin{aligned}
t_{m i} & =t_{i+1}-\Delta t_{i} / 2 \\
\Delta t_{i} & =t_{i+1}-t_{i} \\
f_{i} & =m_{i} /\left(\rho-\Delta t_{i}\right) \\
R_{i} & =A_{i} /\left(A_{0} \cdot s \cdot \Delta t_{i}\right),
\end{aligned}
$$

where $f_{i}$ is the flow rate in $\left(\mathrm{cm}^{3} / d\right), m_{i}$ is the mass $(g)$ of effluent collected in time $\Delta t_{i}$ (d), $p$ is the density of the effluent in $\left(\mathrm{g} / \mathrm{cm}^{3}\right), s$ is the surface area of the sample in $\mathrm{m}^{2}, \mathrm{R}_{i}$ is the leach rate in. $\left(\mathrm{g} / \mathrm{m}^{2}\right.$ - d), $\mathrm{A}_{\mathrm{O}}$ is the specific activity in the original sample (dpm/g), and $i_{j}$ is the activity (dpm) leached during time $\Delta t_{i}$. An example of the experimental results is shown in Fig. 7 and Table: 3, for a sample of silicate puddle glass from a nuclear event at the Nevada Test site. 15 Here, the leach rate $\mathrm{R}$ decreases with time in agreement with a relation discussed by Dievisid ${ }^{16}$ :

$$
R=a t^{-0.5}+b
$$

where the first term corresponds to diffusion through surface film and the second term corresponds to dissolution of the silicate high-polymer network, as rate-determining steps. The nearly identical leach rates of the co isotopes are in agreement with their production early in the course of the nuclear event, and highly similar chemical behavior guring melting and solidification of the puddle glass. Leach rates increase with flow rates, but this is probably not significant except for the first two days. The flow rates are constant within \pm 118 for the high rate, and within \pm 48 fo: the low rate. 


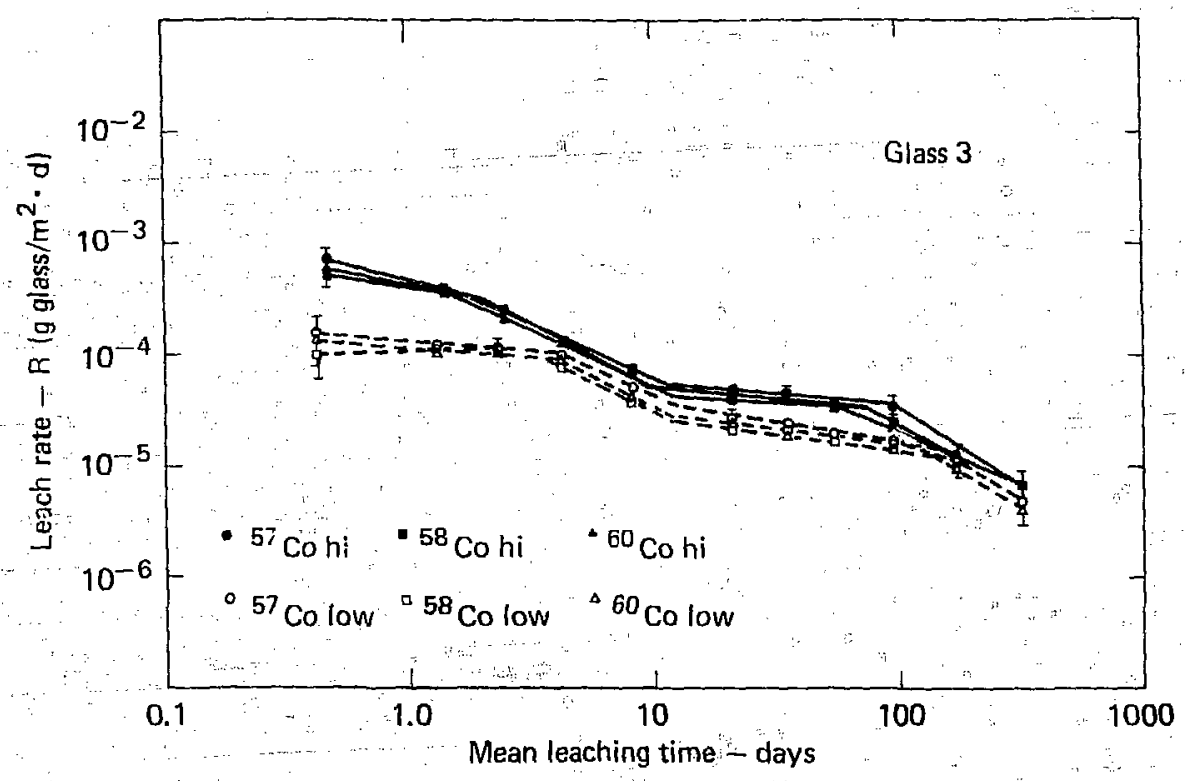

FIG. 7. Leach rate of co isotopes vs time for glass no. 3. 
TABLE 3. Leaching rate:s for Co isctopes in glass no. 3.

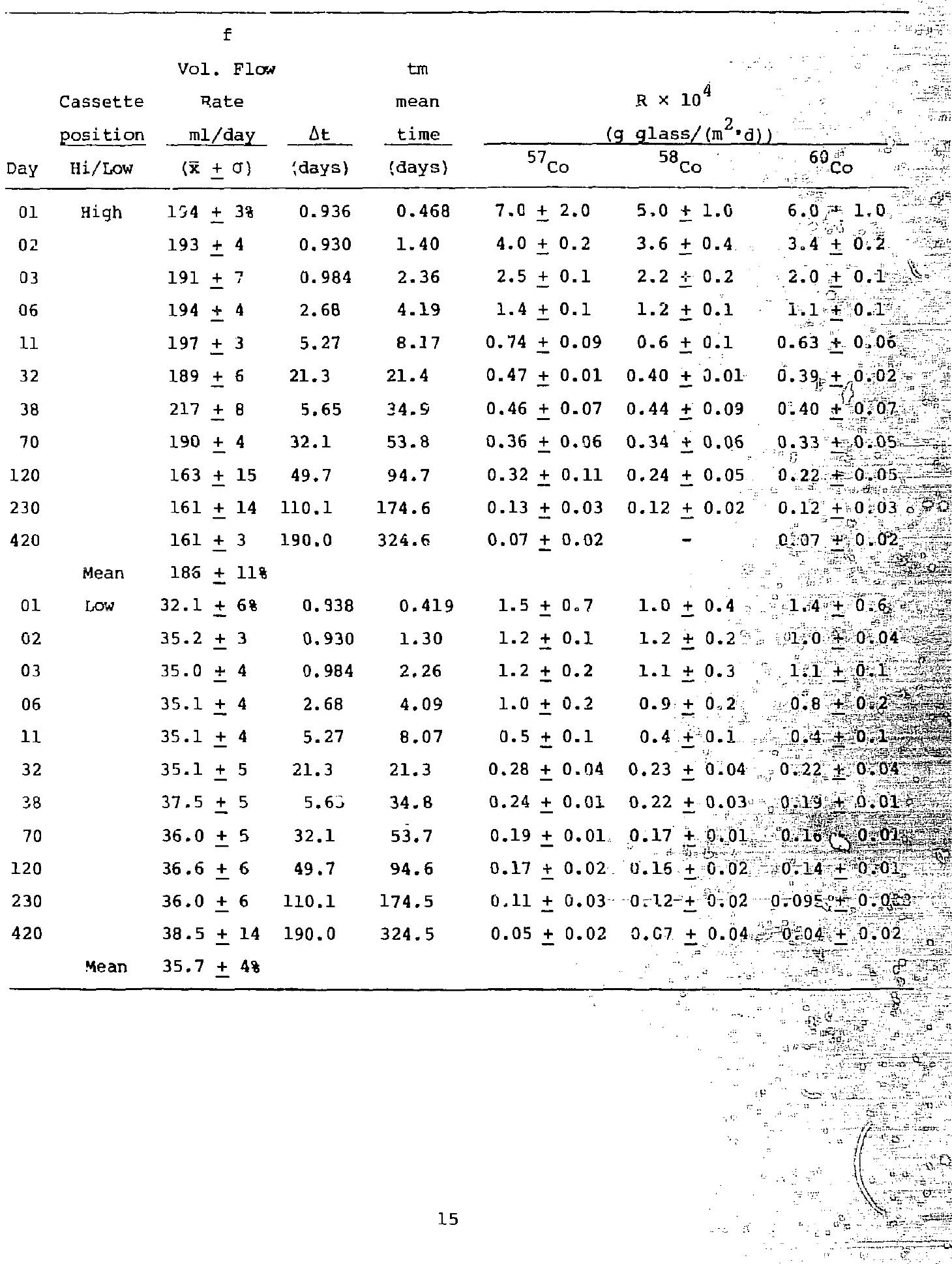




\section{CONCLUSIONS}

We have designed and operated a leaching system with the following features:

- continuously-variable flow rate, from 13 to $460 \mathrm{~cm}^{3} / \mathrm{d}$,

- operating temperature from 25 to $75^{\circ} \mathrm{C}$,

- performance of up to 20 simlicaneous experiments,

- continuous exposure of samples to fresh solution,

- retention in the sample cell of particles down to $0.1 \mu \mathrm{m}$ in diameter,

- collection and gamma-counting of transported radionuclides in a solid polyethylene cylinder.

Results obtained on silicate pudale glass from a nuclear event are in qualitative agreement with those on silicate glasses designed for isolation of nuclear-reactor waste. 


\section{REFERENCES}

1. I. E. Mendel, A Review of Leaching Test Methods and the Leachability of Various Solid Mediacontaining Radioactive wastes, Battelle Pacific Northwest Laboratories Richland, WA, BNWL-1765 (JulY 1973).

2. D. J. Bradley, "Leaching of Fully Radioactive High-Level waste Glass and Waste-Geologi Environment Interaction Studies," in Radioactive waste in Geo,logic Storage, sherman Fried, ed, (ACS symposium Series 100, American Chemical Society, washington, DC, 1979), pp. 75-91.

3. K. F. Flynn, $\mathrm{L}$-J Jardine, and $\mathrm{J}$. J. Steindler, "Method for Determining Leach Rates or Simulated Radioactive Waste Forms, in Radioactive Waste in Geologlc storage, Sherman Fried, ed, (ACS Sympos, um Series 100, Americun Chemical society, Washington, DC, 1979), po. 115-127.

4. K. Scheffler, U. Riege, K. Louwrier, HJ. Matzke, I. Ray, and H. Thiele, Long-Term Leaching of Silicate systems: Testing Procedure, Actinides Behavious and Mechanism, Kernforschungszentrum Karlsruhe, Ges. Fur Kernforschung mbH, Kar lsruhe, F.R.G., KFK2456, EUR55093, PWA 34/77 (June $1977)$.

5. R. C. Rastogi, J. D. Sehgal, K. Chandrin, and K. T. Thomas, Investigation of Materials and Methods for Fixation of Low and Medium Level Radioactive waste in Stable solid Media, Final Regort, Bhabha Atomic Research Centre, Bombay, India, BARC-400 (1969).

6. Göran Blomqvist, Leaching Experiments with Highly Radioactive French Glasses at Studsvik, Aktiebolaget Atomenergi, Studsvik, Sweden, KBS-50 (30 November 1977).

7. J. Aelley, Evaluation of Glass as a Matrix for solidification of Savannah River Plant Waste. Nonradioactive ana Tracer Studies $E$. I. dupont De Nemours and Co., Savannah River Laboratory, Aiken, sc 29801 , $\mathrm{DP}-1382$ (May 1975).

8. J. A. Kelley and R. M. Wallace, "Procedure col Determining Leachabilities of Radioactive Waste Forms," Nuclear Technology 30, 47-51 (1976).

9. W. F. Merritt, "High Level Waste Glass, Field Leach Test, " Nuclear Technology 32, 88-91 (1977). 
10. N. N. Elliott and D. B. Auty, The Durability of FINGAL Glass, Part I. Discussion of Method and Effect of Leaching Conditions, Acomic Energy Research Establishment, Harwell, UK, AERE-R5151 (March 1967).

11. A. R. Bancroft and J. D. Gamble, Initiation of a Field Burial Test of the Disposal of Fission Products Incorporated into Glass, Atomic Energy of Canada, Ltd., Chalk River, Ont., Canada, CRCE-808 (November 1958).

12. W. Heimer1, H. Heine, L. Kahl, H. W. Levi, W. Lutze, G. Malow, E. Scheiner, and P. Schubert, Research on Glasses for Fission Product Fixation, Summary Report, January 1968-June 1971, Hahn-Meitner Institute, Berlin, HMI-Bl09 (September 1971).

13. B. E. Paige, Leachability of Glass Prejared from Highly Radioactive Calcined Alumira Waste, Phillips Petroleum Co., Atomic Energy Division, Idaho operations OEfice, USAEC, Idaho Falls, ID, IDO-14672 (February 1966).

14. I. Y. Borg, R. Stone, H. B. Levy, and L. D. Ramspott, Information Pertinent to the Migration of Radionuclides in Ground Water at the Nevada Test Site, Part 1: Review and Analysis of Existing Information, Lawrence Livermore Laboratory, Livermore, CA, UCRL-52078, Part 1 (1976).

15. D. G. Coles, H. C. Weed, and J. S. Schweiger, Single-Pass Leaching of Nuclear Melt Glass by Groundwater, Part II, Lawrence Livermore Laboratory, Livermore, CA, UCRL-81617, Part 2 (in preparation).

16. F. E. Diebold, Discussion of Glass-Water Interactions, Atlantic Richfield Hanford Co., Richland, WA, ARH-2905 (September 15, 1973). 